\title{
Valinta ja valikoituminen tuoreesta näkökulmasta
}

Risto Rinne, Nina Haltija, Hanna Norri ja Arto Jauhiainen (2008). Yliopiston porteilla. Aikuisten ja nuoret hakijat ja sisäänpäässeet 2000-luvun alun Suomessa. Kasvatusalan tutkimuksia 18. Suomen kasvatustieteellinen seura. 424 sivua.

$\mathrm{R}_{\mathrm{i}}$ isto Rinteen johtaman turkulaisen tutkijajoukon viime vuonna ilmestynyt julkaisu eri-ikäisten - pääasiallisesti aikuisten ihmisten hakemisesta ja sisäänpääsystä yliopistoon on monella tapaa uusia uria avaava ja tärkeä kirja. Se on itse asiassa ensimmäisiä teoksia, joka käsittelee aikuisten yliopisto-opintoihin osallistumista ja uranuurtaja osallistumisen tilastollisessa tarkastelussa laajalla aineistolla.

\section{Laaja tarkastelu - suppeaa kritiikkiä}

Rinteen ja kumppanien tarkastelun kohteena ovat yliopistoihin hakeneet ja sisään päässeet aikuiset 2000-luvun alun Suomessa. Aineisto on kerätty vuosien 2000-2003 rekisteritiedoista, joten kovin pitkää ajallista vertailua sen pohjalta ei ole mahdollista tehdä. Toki on hyvä muistaa, että aikuisten laajamittainen yliopisto-opiskelu on leimallisesti viime vuosien ja vuosikymmenten ilmiö. Kunnollista suomalaista tutkimustakaan ei aiheesta juuri ole Erja Mooren väitöskirjaa enempää. Kirjan keskeisenä tavoitteena on selvittää, mitä reittejä myöten ja miten aikuisopiskelijat hakevat ja pääsevät yliopistoon sekä verrata aikuisten hakua "nuorten" vastaavaan.
Kirjoittajat liittävät aikuisopiskelijoista saamansa tiedot laajempaa opiskelijoiden taustaa ja valikoitumista koskeneeseen suomalaiseen - ja osin kansainväliseen - tutkimukseen. Tämä on tärkeä ulottuvuus ja auttaa nostamaan esiin tutkimuksen keskeisiä havaintoja - aikuisopiskelijoiden valinnat ja valikoituminen kun ei kaikilta osin käy yksiin "perusopiskelijoista" saadun tiedon kanssa, vaikka samoja piirteitä onkin. Käsite "aikuinen" tarkoittaa yli 25-vuotiaita. Toisaalta aikuisryhmässä on sisäisiä iästä ja elämäntilanteesta johtuvia eroja, joten joukko ei kaikilta osin ole sen yhtenäisempi kuin "tavallisten" yliopistoopiskelijoiden joukkokaan.

Yliopiston porteilla -kirja hyödyntää laajoja rekisteri- ja tilastoaineistoja hakeneista ja hyväksytyistä. Aineiston kattavuutta ei ole syytä asettaa kyseenalaiseksi, vaikka tekijät ovat joutuneet joiltain osin tyytymään otosaineistoon tietosuojamääräysten takia. Tässä he ovat törmänneet monelle tilastoaineistoja käyttävälle tuttuun ongelmaan: tietosuojan kiristyminen saattaa olla kansalaisten oikeusturvan näkökulmasta perusteltua, mutta tutkimuksen kannalta kiusallista, jopa haitallista.

Samoin kirjoittajien kuvailemat rekisteriaineistojen ongelmat ja epätarkkuudet ovat tuttuja monille samojen asioiden parissa puuhanneille. Silti lähes 250000 tapauksen aineistosta saa varmasti luotettavan kuvan aikuisten hakemisesta ja pääsystä yliopistoihin. Lisäksi aineistoa analysoidaan ja sen elementtejä yhdistellään monesta näkökulmasta. Tällöin tulevat käsitellyiksi paitsi aikuisopiskelijoiden tausta ja valikoituminen, myös erilaisella motiivilla ja erilaisia reittejä pitkin opiskelemaan tulleet sekä yliopistojen ja tieteenalojen väliset erot "aikuisopiskelijamyönteisyydessä”.

Kirjan kirjoittajat kävivät viime vuoden lopulla Kasvatuslehdessä keskustelua Osmo $\mathrm{Ki}$ visen, Juha Hedmanin ja Päivi Kaipaisen kanssa ennen kaikkea johdanto-osioon sijoittuvasta katsauksesta koulutusmahdollisuuksien eriarvoisuuden muuttumiseen ja siihen liittyvän oddssuhteen luonteesta ja tulkinnasta. Tässä keskustelussa tutkimuksen muut elementit jäivät kokonaan syrjään, joten käsittelen itse niitä jatkossa enemmän. Totean vain, että koska molemmat tutkijaryhmän edustavat Turun yliopistoa, toteutunee tässä oppiaineryhmämme karismaattisen johtajat toteamus: "yksimielinen työyhteisö ei ole luova".

\section{Eroja ja yhtäläisyyksiä}

Rinteen, Haltian, Norrin ja Jauhiaisen kirja sisältää niin paljon tietoa, taulukoita ja kuvioita aikuisopiskelijoista 20 yliopistos- 
samme, että kaikkea on mahdotonta lähteä purkamaan. Siksi otan esille mielestäni kiintoisimpia havaintoja ja tulkintoja.

Ensimmäisenä voi nostaa esiin lähtökohtaisen ja tuloksissa näkyvän eron nuoriin opiskelijoihin taustojen osalta. Esimerkiksi sosioekonomisen tausta yhteys hakemiseen ja sisäänpääsyyn oli selvästi voimakkaampi nuorilla kuin aikuisilla yliopistoopiskelijoilla. Tämä selittyy pitkälti sillä, että aikuisiällä yliopistoon tulleilla oli takanaan opintoja - joskus jopa ensimmäinen yliopistotutkinto. Toisaalta aikuiset olivat harvemmin ylioppilaita kuin nuoret yliopistoissa aloittaneet. Tässä siis todentui usein havaittu ilmiö, jonka mukaan vanhempien koulutus- ja sosiaalitaustan vaikutus vähenee koulutusuran edetessä. Läheskään kokonaan se ei silti häviä, kuten kirjassakin osoitetaan.

Kiintoisa kirjassa todennettu elementti on yliopistokentän lohkoutuminen. Tieteenalojen erilaisuuden opiskelijoiden taustan, yhteiskunnallisen statuksen ja koulutuspoliittisen merkityksen osalta ovat toki useat tutkijat tuoneet aikaisemmin esille. Asia on silti vaikkapa yliopistokoulutuksesta käydyssä keskustelussa sivuutettu melko tyystin. Rinne ja kumppanit tuovat tähän oman merkittävän lisänsä analysoimalla yliopistokenttää aikuisten hakijoiden näkökulmasta. Kenttä osoittautuu hyvin heterogeeniseksi ja ääripäät ovat kaukana toisistaan.

Osittain kenttä lohkoutuu perinteisellä tavalla korkean statuksen eliittialoihin, joille aikuisten tiekin on kivikkoisin sekä "kansanomaisempiin" aloihin, jonne pääsy on helpompaa ja opiskelijoina siksi (tai siitä huolimatta) paljon naisia ja alemmista sosi- aaliryhmistä lähteneitä. Tällaisen tulkinnan voi tehdä vaikkapa sivun 252 erinomaisen kuvion perusteella.

Toisaalta aikuisten näkökulmasta yliopistokentästä löytyy melkoisia erikoisuuksia. Kovin yllättävää ei vielä ole se, että kasvatustieteelliselle alalle hakeutuu paljon ylempiä toimihenkilöitä. Onhan ala tärkeä pätevöittämiskouluttaja vaikkapa opettajille, henkilöstöasioista vastaaville tms. Kuvioon sopii hyvin myös se, että teologiselle tai humanistiselle alalle hakeutuu suhteessa paljon alemmista ryhmistä lähtöisin olevia. Sen sijaan yllättävää on, että odds-suhteella mitattuna Joensuun yliopiston metsätieteelliseen tiedekunta osoittautuu kaikkein karsivimmaksi. Tiedekunta valikoi siis varsin rankasti aikuisopiskelijoita, sillä edelle menee vain Kuopion yliopiston farmasian opetus. Joensuun metsätieteelliseen opetukseen ylemmän toimihenkilön jälkeläinen pääsee lähes viisi kertaa todennäköisemmin kuin työntekijätaustainen hakija. Perinteisesti ja tutkimusten mukaankin Joensuun metsätieteellinen opetus on rekrytoinut kohtuullisen keskiluokkaista opiskelijakuntaa nuorista aloittajista. Aikuisopiskelijoilla tilanne on siis toinen.

Erityisenä ansiona kirjassa mielestäni on aikuisten opiskelijoiden erilaisten reittien hahmottaminen ja valikoitumisprosessin tarkastelu myös tästä näkökulmasta. Isossa kuviossa katsottuna toki niin sanotut päävalinnat eli "normaali" hakumenettely on määrällisesti hallitseva. Se kuitenkin suosii, kuten kirjoittajatkin toteavat, selkeästi nuorimpia ikäluokkia. Koulutuspoliittisessa päätöksenteossa tunnutaan lisäksi olevan valmiita suo- simaan nuoria entistä enemmän. Paljoakaan ei ole kysytty, onko tämä yliopistojen tai vaikkapa aikuisopiskelijoiden kannalta viisasta. Rinne ja kumppanit kuitenkin osoittavat, miten muiden reittien - avoin yliopisto, muuntokoulutus, maisterikoulut ja muut reitit - merkitys kasvaa iän myötä. Vaikea on uskoa, että muita reittejä saisimme yliopistoihin lähtökohtaisesti huonompaa tai vähemmän motivoituneita opiskelijoita.

Kokonaisuutena arvioiden Yliopiston porteilla -kirja on tärkeä perustutkimus vähän tunnetusta, mutta jatkuvasti kasvavasta ilmiöstä. Tietoa kirjassa on niin paljon, että ajoittain lukijalta vaaditaan kärsivällisyyttä ja jonkinmoisia perusvalmiuksia kaiken irti saamiseksi ja sulattamiseksi. Ehkäpä esittämistä olisikin paikka paikoin voinut tiivistää ja nostaa olennaisen selkeämmin esille. Tosin jokaisen pääluvun lopussa olevat yhteenvedot ja loppuyhteenveto tiivistävät onnistuneesti keskeisiä asioita. Ajoittainen raskaslukuisuus ei silti syö teoksen perustavanlaatuisuutta tai tieteellistä painoarvoa. Isosta ja moniulotteisesta ilmiöstä kun ei aina ole mahdollista kirjoittaa hyvin yksinkertaisesti tai lehdistötiedotemaisesti.

\section{Arto Nevala}

\section{Virheellinen otsikko}

Numerossa 2/2009 lehti julkaisi sisällysluettelossa ja summaryssä Pirjo Ståhlen ja Tuomo Kuosan artikkelista virheellisen otsikon. Oikea on itse artikkelin yhteydessä oleva: Systeeminen itseuudistuminen - uutta ymmärrystä kollektiivien kehittymiseen. 